\title{
cryptogande
}

\section{Novelties on Tortella (Pottiaceae, Bryophyta) from South America}

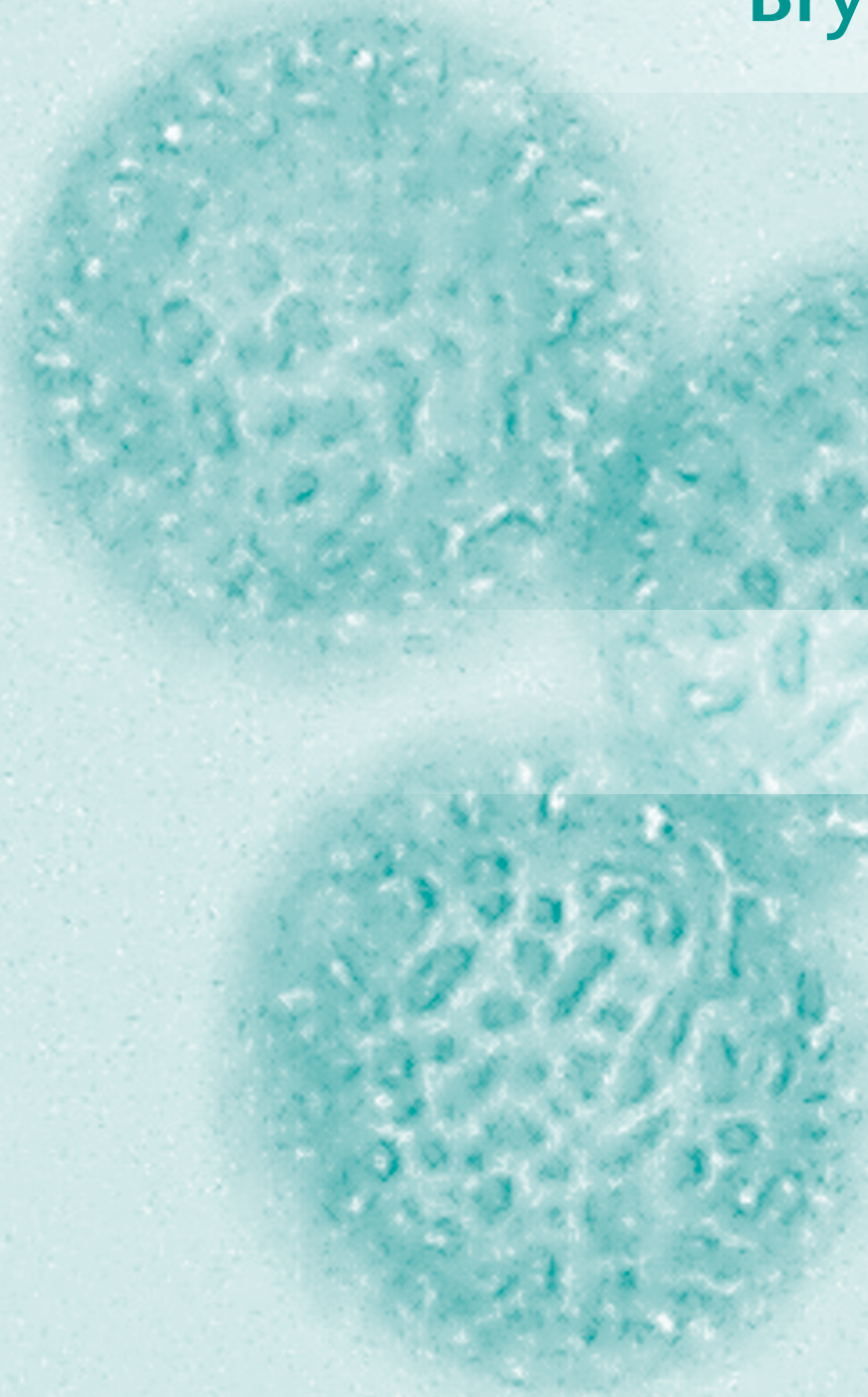

Soledad JIMENEZ, Guillermo M. SUÁREZ \& Richard H. ZANDER 
DIRECTEUR DE LA PUBLICATION: Bruno David,

Président du Muséum national d'Histoire naturelle

RÉdACTEURS EN CHEF / EDITORS-IN-CHIEF : Denis LAMY

ASSISTANTS DE RÉDACTION / ASSISTANT EDITORS: Marianne SALAÜN

MISE EN PAGE / PAGE LAYOUT: Marianne SALAÜN

RÉdACTEURS ASSOCIÉS / ASSOCIATE EDITORS

Biologie moléculaire et phylogénie / Molecular biology and phylogeny

Bernard GOFFINET

Department of Ecology and Evolutionary Biology, University of Connecticut (United States)

Mousses d'Europe / European mosses

Isabel DRAPER

Centro de Investigación en Biodiversidad y Cambio Global (CIBC-UAM), Universidad Autónoma de Madrid (Spain)

Francisco LARA GARCÍA

Centro de Investigación en Biodiversidad y Cambio Global (CIBC-UAM), Universidad Autónoma de Madrid (Spain)

Mousses d'Afrique et d'Antarctique / African and Antarctic mosses

Rysiek OCHYRA

Laboratory of Bryology, Institute of Botany, Polish Academy of Sciences, Krakow (Pologne)

Bryophytes d'Asie / Asian bryophytes

Rui-Liang ZHU

School of Life Science, East China Normal University, Shanghai (China)

Bioindication / Biomonitoring

Franck-Olivier DENAYER

Faculté des Sciences Pharmaceutiques et Biologiques de Lille, Laboratoire de Botanique et de Cryptogamie, Lille (France)

Écologie des bryophytes / Ecology of bryophyte

Nagore GARCÍA MEDINA

Department of Biology (Botany), and Centro de Investigación en Biodiversidad y Cambio Global (CIBC-UAM), Universidad Autónoma de Madrid (Spain)

COUVERTURE / COVER:

Extraits d'éléments de la Figure 2 / Extracts of the Figure 2

Cryptogamie, Bryologie est indexé dans / Cryptogamie, Bryologie is indexed in:

- Biological Abstracts

- Current Contents

- Science Citation Index

- Publications bibliographiques du CNRS (Pascal).

Cryptogamie, Bryologie est distribué en version électronique par / Cryptogamie, Bryologie is distributed electronically by:

- BioOne ${ }^{\circledR}$ (http://www.bioone.org)

Cryptogamie, Bryologie est une revue en flux continu publiée par les Publications scientifiques du Muséum, Paris Cryptogamie, Bryologie is a fast track journal published by the Museum Science Press, Paris

Les Publications scientifiques du Muséum publient aussi / The Museum Science Press also publish:

Adansonia, Geodiversitas, Zoosystema, Anthropozoologica, European Journal of Taxonomy, Naturae, Cryptogamie sous-sections Algologie, Mycologie.

Diffusion - Publications scientifiques Muséum national d'Histoire naturelle

CP $41-57$ rue Cuvier F-75231 Paris cedex 05 (France)

Tél. : 33 (0)1 40794805 / Fax: 33 (0)1 40793840

diff.pub@mnhn.fr / http://sciencepress.mnhn.fr

(C) Publications scientifiques du Muséum national d'Histoire naturelle, Paris, 2019

ISSN (imprimé / print): 1290-0796 / ISSN (électronique / electronic): 1776-0992 


\title{
Novelties on Tortella (Pottiaceae, Bryophyta) from South America
}

\author{
Soledad JIMENEZ \\ Instituto de Botánica del Nordeste (IBONE-CONICET-UNNE), \\ Sargento Cabral 2131, Casilla de correo 209, Corrientes (Argentina) \\ soledadjimenez@conicet.gov.ar (corresponding author) \\ Guillermo M. SUÁREZ \\ Unidad Ejecutora Lillo, CONICET, Fundación Miguel Lillo, \\ Miguel Lillo 251, San Miguel de Tucumán 4000, Tucumán (Argentina) \\ and Facultad de Ciencias Naturales e Instituto Miguel Lillo, \\ Universidad Nacional de Tucumán, Miguel Lillo 205, \\ San Miguel de Tucumán 4000, Tucumán (Argentina)
}

Richard H. ZANDER

Missouri Botanical Garden, PO Box 299, St. Louis, MO 63166-0299 (United States)

Submitted on 20 February 2018 | Accepted on 15 November 2018 | Published on XXX 2019

KEY WORDS Autoicous species,

Barbula,

Bryophyta,

cleistocarpous,

Paraguay,

stegocarpous,

Uruguay.

MOTS CLÉS Espèces autoöques,

Barbula,

Bryophyta,

cléistocarpes,

Paraguay,

stégocarpes,

Uruguay.
Jimenez S., Suárez G. M. \& Zander R. H. 2019. - Novelties on Tortella (Pottiaceae, Bryophyta) from South America. Cryptogamie, Bryologie 40 (7): 40-50. https://doi.org/10.5252/cryptogamie-bryologie2019v40a7. http://cryptogamie. com/bryologie/40/7

\section{ABSTRACT}

During recent botanical surveys undertaken in South America (Uruguay and Paraguay) some of the samples collected were identified as Tortella fruchartii (Müll. Hal.) R. H. Zander and T. lilliputana (Müll. Hal. ex G. Roth) R. H. Zander, two autoicous species of the genus with distribution area restricted to the New World. The former is re-described based on recent collections from Uruguay, where it has not been found since its original description in 1888; while the latter is recorded for the first time from Paraguay. Detailed descriptions, illustrations in LM and SEM, and a distribution map of the two species are here presented.

\section{RÉSUMÉ}

Deux nouveaux signalements dans le genre Tortella (Pottiaceae, Bryophyta) pour l'Amérique du Sud Lors de récentes excursions botaniques en Amérique du Sud (Uruguay et Paraguay), Tortella fruchartii (Müll.Hal.) R. H. Zander et T. lilliputana (Müll.Hal. ex G.Roth) R. H. Zander ont été récoltées, deux espèces autoïques du genre dont la distribution est restreinte au Nouveau Monde. Tortella fruchartii est redécrit sur la base de récentes récoltes d'Uruguay, où il n'avait pas été retrouvé depuis sa première description en 1888, tandis que T. lilliputana est signalé pour la première fois au Paraguay. Les deux espèces sont décrites en détail, avec des illustrations en microscopie optique et à balayage, et une carte de distribution des deux espèces est donnée. 


\section{INTRODUCTION}

The southernmost extent of South America includes Argentina, southern Brazil, Chile, Paraguay and Uruguay. This area is known as "Cono Sur" and it extends south of parallel $20^{\circ} \mathrm{S}$ from the Atlantic Ocean to the Pacific Ocean. This territory covers a total of $4708617 \mathrm{~km}^{2}$, which represent $26 \%$ of the total surface of South America (Zuloaga et al. 2008). Despite the geographic size and biodiversity richness, the bryoflora of the area is still poorly known. The extant floras and checklists of the mosses from South America (Bartram 1949; Delgadillo et al. 1995; Boggan et al. 1997; He 1998; Churchill et al. 2000, 2009; Gradstein et al. 2001; Matteri 2003, 2004; O'Shea \& Price 2008; Müller 2009; O'Shea 2010 ) in addition to recent discoveries on mosses (e.g. Ellis et al. 2011, 2012a, b; Suárez \& Schiavone 2013; Flores \& Suárez 2014; Suárez et al. 2014, 2017; Cañiza et al. 2017; Jimenez \& Suárez 2017, among others) have highlighted the importance and singularity of the regional flora, especially in Uruguay and Paraguay where references on mosses are scanty and disperse.

The main objective of this paper is to increase the knowledge of the bryophyte flora in South America. We also particularly hope to illuminate the distributions of two very odd much reduced species of the genus Tortella (Müll. Hal.) Limpr.

Particular objectives includes: i) to describe in detailed the species found in Uruguay and Paraguay; and ii) to illustrate in detail by using light microscopy (LM) and scanning electron microscopy (SEM) the diagnostic characters of the taxa, and iii) to delimit its current range of distribution.

\section{MATERIAL AND METHODS}

Several botanical surveys were undertaken by the second author in Uruguay and Paraguay during 2011-2012 within the framework of a major project entitled "Study of the bryophytes of Southern South America (Systematics and Phylogeny)".

The specimens were studied morphologically following classical techniques for bryophytes, and mounted in Hoyer's solution (Anderson 1954). Microscopic characters were analyzed by using LM Leica Model CME, and SEM JEOL 5800 LV operating at $20 \mathrm{KV}$. Characters illustrated using SEM were obtained from samples fixed in Formaldehyde-acetic acid-alcohol-water (FAA), critical-point dried, mounted on double-sided tape and coated with gold-palladium. Spores were obtained from mature capsules, removed with FAA, mounted directly on aluminum stubs and subsequently coated with gold-palladium. Spores were described following the concepts of McClymont (1955) and Punt et al. (2007).

The samples are kept in the herbaria of the Instituto de Botánica del Nordeste, Corrientes, Argentina (CTES), Fundación Miguel Lillo, San Miguel de Tucumán, Tucumán, Argentina (LIL) and Missouri Botanical Garden, St. Louis, Missouri, USA (MO).

\section{RESULTS}

Within the samples collected, two of them matched with two autoicous species of the genus Tortella: T. fruchartii (Müll. Hal.) R. H. Zander and T. lilliputana (Müll. Hal. ex G. Roth) R. H. Zander. The former was recorded in Uruguay and the second in Paraguay.

For both species detailed descriptions, illustrations with LM and SEM are here given, as well as world distribution data.

\section{Tortella fruchartii (Müll. Hal.) R. H. Zander}

(Figs 1;2)

In Bulletin of the Buffalo Society of Natural Sciences 32: 104 (1993). - Phascum fruchartii Müll. Hal., Flora 71: 4 (1888). - Systegium fruchartii (Müll. Hal.) Kindb., Enumeratio Bryinearum Exoticarum, Supplementum 95. (1889) - Astomum fruchartii (Müll. Hal.) Broth., Bihang till Kongliga Svenska Vetenskaps-Akademiens Handlingar 26 Afd. 3(7): 19 (1900). — Type: Uruguay, Montevideo, en la terra, VIII.1874: Arechavaleta 205, in Hb. Lund. (syn-, H!, NY!)

Astomum latifolium Broth., Aussereur. Laubm. 190. 17 f. 8 (1910). Type: Brazil, Porto Allegre (Brasilien), bei der Vorstadt Saó Joaó, auf Erdböschungen, E. M. Reineck \& J. Czermak 222, 23.V.1899 (iso-, BM!).

Specimen EXAmined.- Uruguay. Rocha, Parque Fortaleza Santa Teresa, 3358'39"S, 5332'17"W, 33 m, sobre suelo, 3.I.2011, G. Suárez 1047 (CTES, LIL, MO).

Geographical distribution. New World species described by Müller (1888) from Uruguay and later reported from Brazil (Roth [1910-] 1911; Yano 1981), Mexico (Delgadillo \& Cárdenas 1996) and Paraguay (Brotherus 1900; Buck 1985; O’Shea \& Price 2008) (Fig. 3). This is the second record in Uruguay collected 135 years after original collection in 1874 .

\section{DESCRIPTION}

Plants

Loosely caespitose forming low turfs, yellowish green above, brown below.

\section{Stems}

0.2-0.3 cm long, erect, simple, in cross section rounded to rounded-pentagonal, central strand well-developed, sclerodermis present but usually weak, hyalodermis present, composed of cells that are little collapsed when mature, weakly radiculose, reddish brown rhizoids, axillary hairs ca. $110 \mu \mathrm{m}$ long, 5-6 cells in length, all hyaline.

\section{Leaves}

Evenly distributed along the stem, erect-flexuose, convolute when dry, spreading when moist, ligulate to lanceolate, 1.7$2.2 \times 0.3-0.4 \mathrm{~mm}$, margins plane, entire at base, weakly crenulate to dentate with projecting papillae below midleaf, apex obtusely mucronate; base oblong, weakly differentiated in shape; costa 106-112 $\mu \mathrm{m}$ in width near base, short excurrent as a mucro, in cross section ovate, ventral and dorsal stereid bands well developed, 6-8 guide cells in 1(-2) layers, hydroid strand absent, ventral epidermis present from base 
A

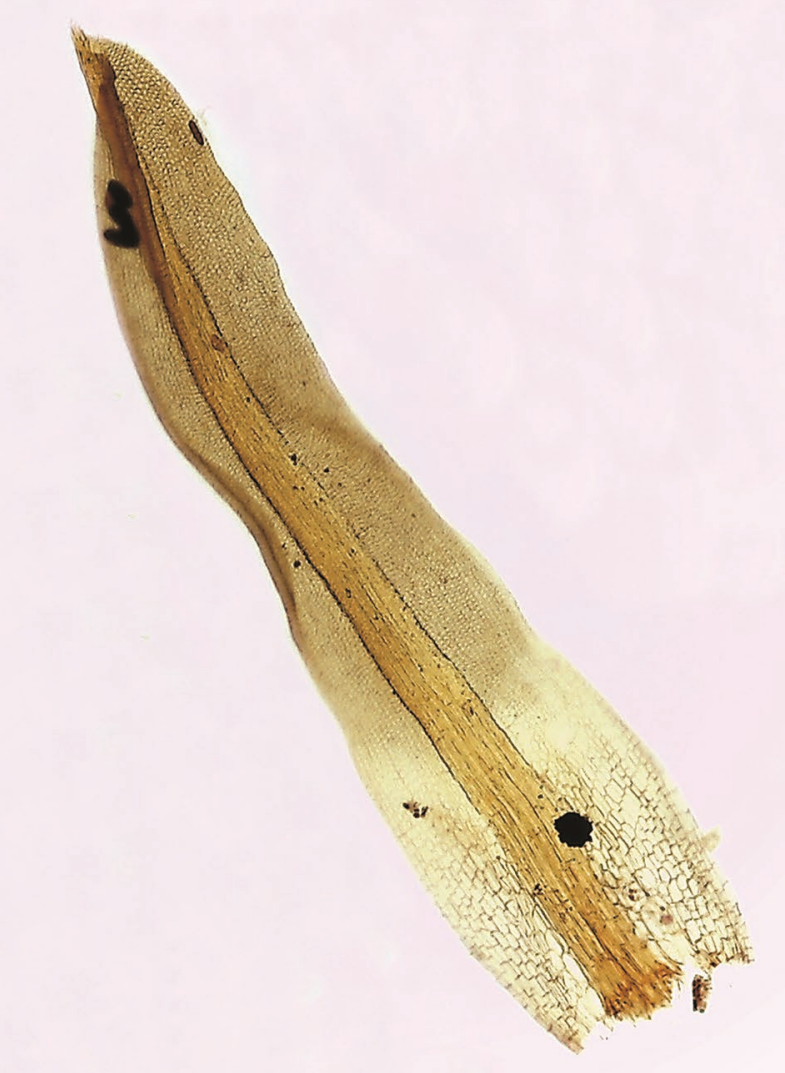

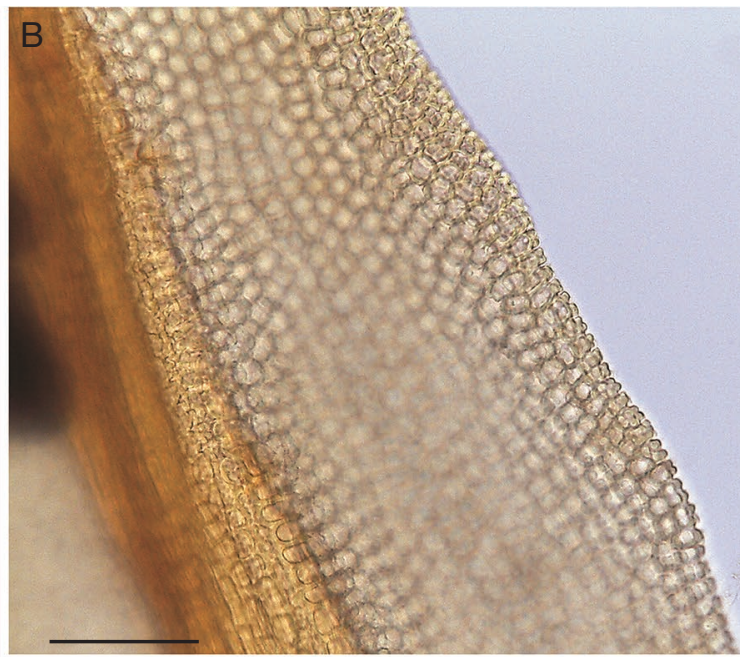

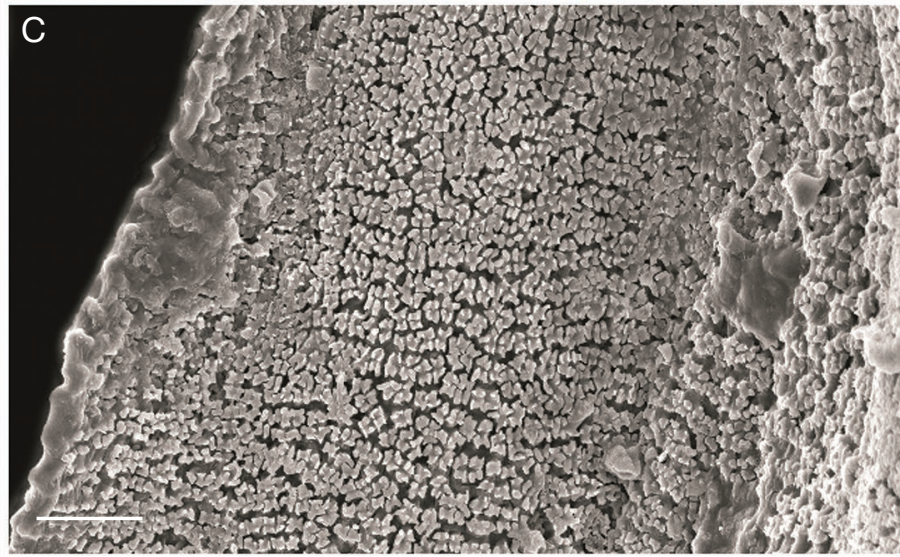

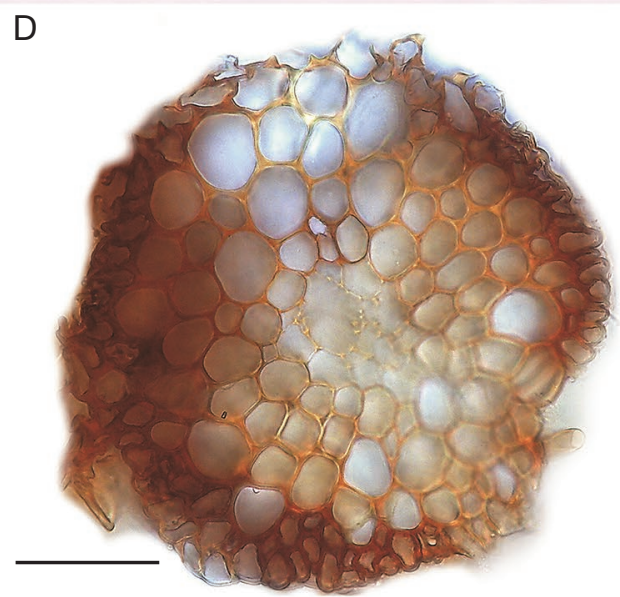

$E$

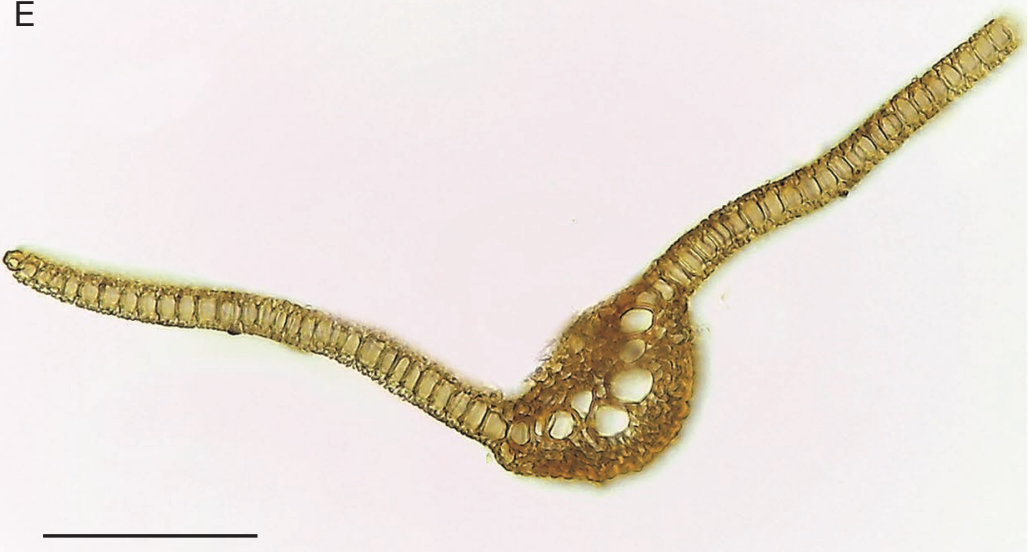

FIG. 1. - Tortella fruchartii (Müll. Hal.) R. H. Zander gametophyte micrographs: A, Vegetative leaf; B, C, Laminal cells at the middle of the leaf; D, Stem cross section;

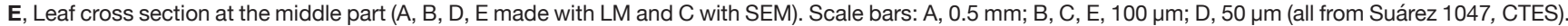

to apex, dorsal weakly developed to absent from base to apex; upper laminal cells quadrate to hexagonal, 8.3-9.9 $\times$ 4.9-6.6 $\mu \mathrm{m}$, walls thin, superficially convex on both sides, papillose, papillae bifid, 3-4 per lumen, basal cells differentiated across leaf in a V-shape, extending $1 / 3$ above the base, well differentiated from the upper cells, long-rectangular to linear, $24-41 \times 3.3-8.3 \mu \mathrm{m}$, walls thin, smooth, gradual transition in a $\mathrm{V}$-shaped.
Autoicous

\section{Perichaetia}

Terminal. Perichaetial leaves little differentiated, lanceolate, $0.7-0.9 \times 0.1-0.3 \mathrm{~mm}$.

\section{Perigonia}

Not seen. 
Seta

Less than $0.1 \mathrm{~cm}$ long.

\section{Theca}

Immersed, ellipsoidal to cylindric, long rostrate, reddish brown; exothecial cells mostly short-rectangular, 54-69 $\times$ 23-28 $\mu \mathrm{m}$, stomata absent, annulus absent, dehiscence by irregular rupture, peristome absent.

\section{Calyptra \\ Cucullate.}

Spores

Bilateral, concave-convex in shape, $16-18 \mu \mathrm{m}$, brown to yellowish brown, rugulate, with long rugulae in distal view, turning short towards proximal view appearing wide verrucae. Laminal $\mathrm{KOH}$ reaction yellow.

Tortella lilliputana (Müll. Hal. ex G. Roth) R. H. Zander (Figs 4; 5)

In Bulletin of the Buffalo Society of Natural Sciences 32: 104 (1993). Phascum lilliputanum Müll. Hal. ex G. Roth., Aussereuropäischen Laubmoose 212. pl. 20:3 (1911). - Tetrapterum lilliputanum (Müll. Hal. ex G. Roth) Broth., Natürlichen Pflanzenfammilien (ed. 2) 10 253. (1924). - Type: Brazil, S. Catharina, Tubarão, ad terram, VIII.1890, (iso-, [E. Ule 133], NY!, S!)

SpeCimen eXAmined. - Paraguay. $3 \mathrm{~km}$ al Norte de Paraguarí, Cerro

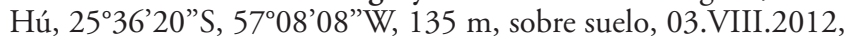
G. Suárez 1488 (CTES, LIL, MO).

GeOgraPhicAl Distribution. - It is a New World species described from Brazil (Roth [1910-] 1911), and later reported from Panama (Crum \& Arzeni 1953). Here is recorded as new to Paraguay (Fig. 3).

\section{DESCRIPTION}

Plants

Forming low turfs, greenish brown below.

\section{Stems}

0.4-0.5 cm long, erect, branching occasionally, in cross section rounded-pentagonal, central strand well-developed, sclerodermis present but usually weak, hyalodermis present, composed of cells that are little collapsed when mature, weakly radiculose, reddish brown rhizoids; axillary hairs 110-150 $\mu \mathrm{m}$ long, 7-8 cells in length, all hyaline.

\section{Leaves}

Often crowded, erect incurved, somewhat contorted when dry, spreading when moist, ligulate to long-lanceolate, 1.5-3.1 $\times$ 0.1-0.3 mm, lamina channeled across leaf, margins incurved, entire at base, weakly crenulate to dentate with projecting papillae below midleaf, apex subulate; base oblong, not differentiated in shape; costa 68-74 $\mu \mathrm{m}$ in width near base, short excurrent as a mucro, in cross section rounded, ventral and dorsal stereid bands well-developed, 4-6 guide cells in 1 layer, hydroid strand absent, ventral epidermis present from base to apex, dorsal epidermis weakly-developed to absent; upper laminal cells quadrate to hexagonal, 6.6-8.3 $\times$ 4.9-8.3 $\mu \mathrm{m}$, walls thin, superficially convex on both sides, papillose, papillae 3-4 per lumen, basal cells differentiated across leaf in a weak V-shape, extending $1 / 3$ above the base, well differentiated from the upper cells, long-rectangular, 28-59 × 8-16 $\mu \mathrm{m}$, walls thin, smooth, gradual transition in a V-shaped.

\section{Autoicous}

\section{Perichaetia}

Terminal, gemmiform. Perichaetial leaves lanceolate, 1.5-1.9 $\times 0.1-0.3 \mathrm{~mm}$, the inner smaller than the outer.

\section{Perigonia}

Terminal, gemiform. Perigonial leaves lanceolate, $0.4-1.1 \times$ 0.1-0.3 mm, the inner smaller than the outer. Seta $0.4-0.5 \mathrm{~cm}$, twisted clockwise below.

\section{Theca}

Exserted, ellipsoidal, reddish brown; exothecial cells mostly rectangular to long-rectangular, 41-68 × 24-31 $\mu \mathrm{m}$, stomata at base of theca, phaneropore, annulus absent or weak and non-functional, dehiscence by the fall of the long rostrate operculum, peristome absent.

\section{Calyptra \\ Cucullate}

\section{Spores}

Bilateral, concave-convex in shape, 19-24 $\mu \mathrm{m}$, yellowish-brown, papillose, papillae low and blunt homogenously distributed on both views.

\section{Laminal \\ $\mathrm{KOH}$ reaction yellow.}

\section{DISCUSSION}

The name Tortella was first used by Müller (1849) for a section in the genus Barbula Hedw. (Barbula section Tortella Müll. Hal.) and later elevated to the generic level by Limpricht (1888). The morphological traits that define Tortella include the presence of a well-developed hyalodermis, the chlorophyllose, quadrate upper laminal cells distinctly differentiated from the usually hyaline, rectangular basal leaf cells, which run up the basal margin in a V-shaped pattern (Zander 1993; Eckel 1998; Allen 2002). Nevertheless Werner et al. (2014) showed by molecular phylogenetic analyses that the $\mathrm{V}$-shaped line of demarcation between the basal hyaline cells and the distal chlorophyllose cells cannot be used to refer all species of Tortella, and that the characterization of the genus based on this character is inaccurate.

The genus Tortella includes both cleistocarpic and stegocarpic species, condition not necessarily infrequent in Pottiaceae (Werner et al. 2002; Flores \& Suárez 2017). Despite sporophytic characters have been widely used to 


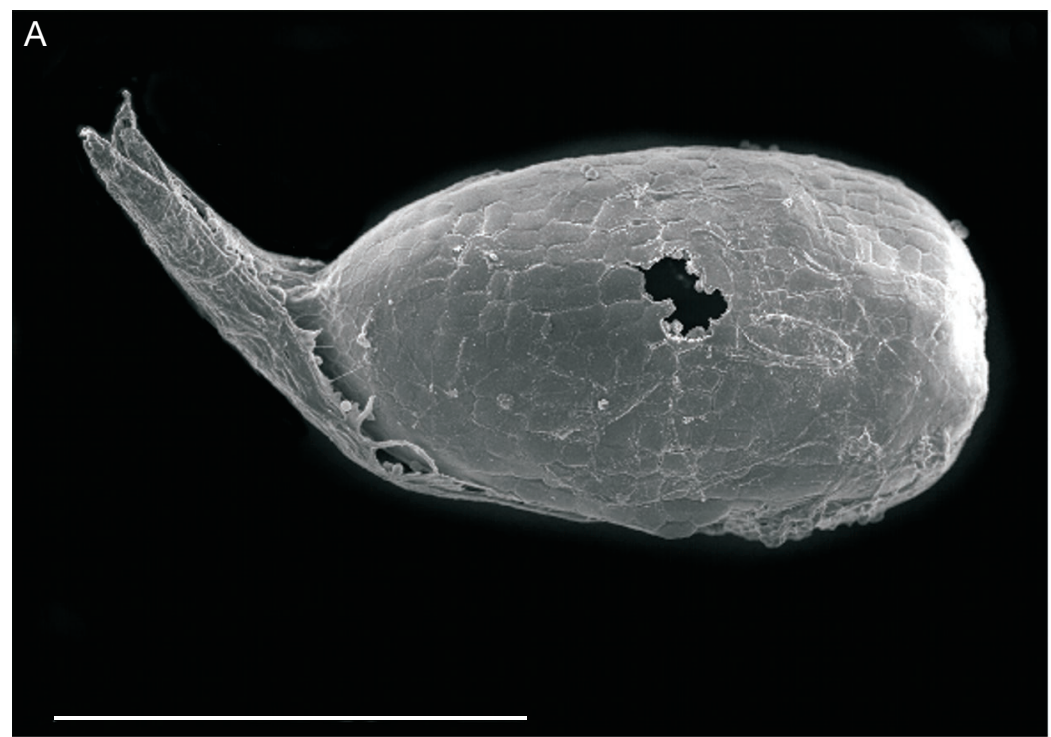

B
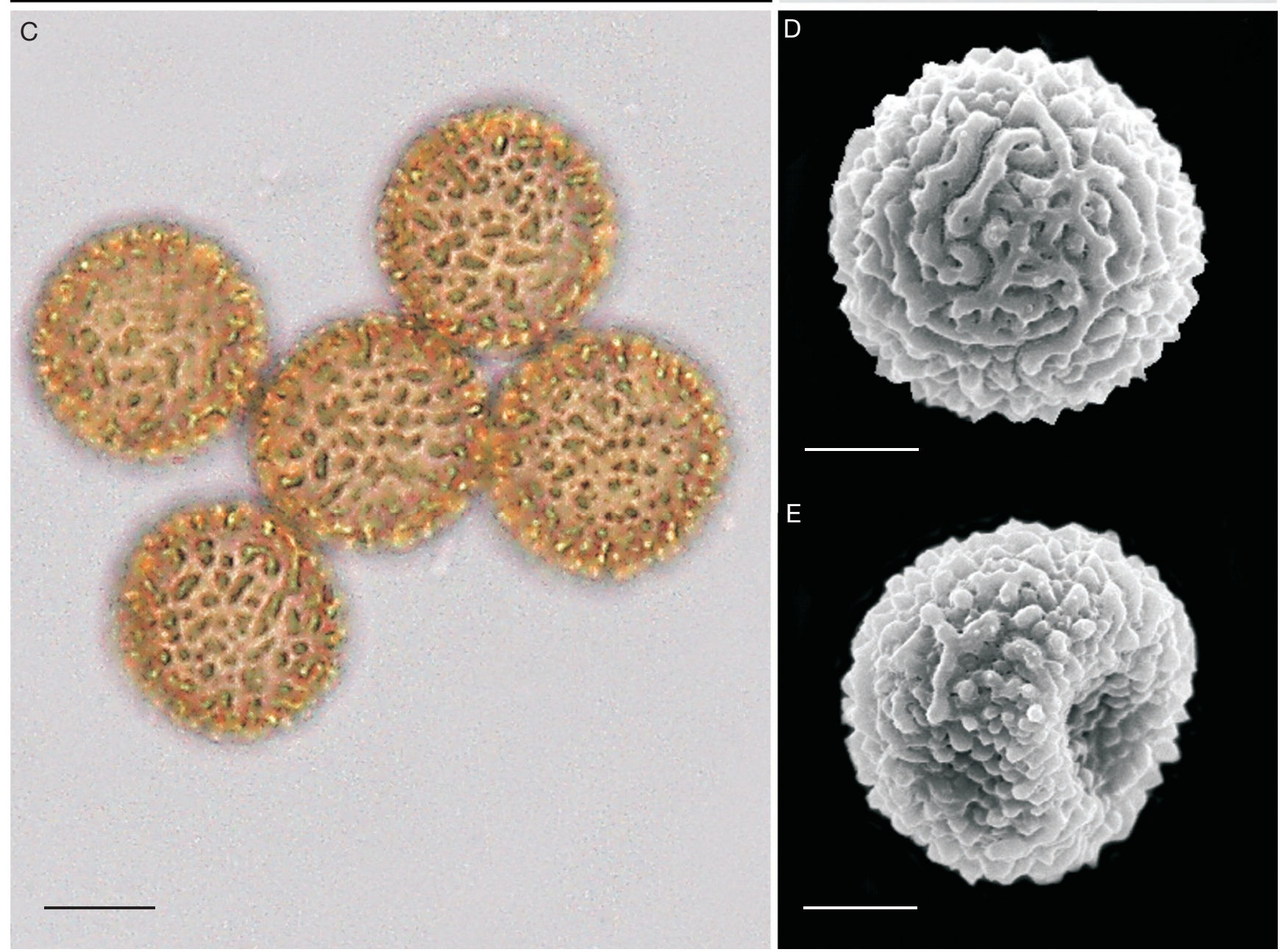

FIG. 2. - Tortella fruchartii (Müll. Hal.) R. H. Zander sporophyte and spores micrographs: A, Capsule showing apicule covered by the calyptra; B, Capsule irregularly ruptured; C, Spores; D, Spore detail in distal view; E, Spore detail in proximal view (A, D, E made with SEM and B, C with LM). Scale bars: A, B, 0.5 mm; C, $10 \mu \mathrm{m}$; D, E, 5 um (all from Suárez 1047, CTES).

define relations at high levels, Zander (1993) emphasized the information content of the characters of the gametophyte and generalizes the use of sporophytic characters at specific levels.
Tortella fruchartii and T. lilliputana have been described as being cleistocarpic, been considered this character diagnostic for the distinction from all other members of Tortella (Zander 1993; Allen 2002). Nevertheless, the study of the 


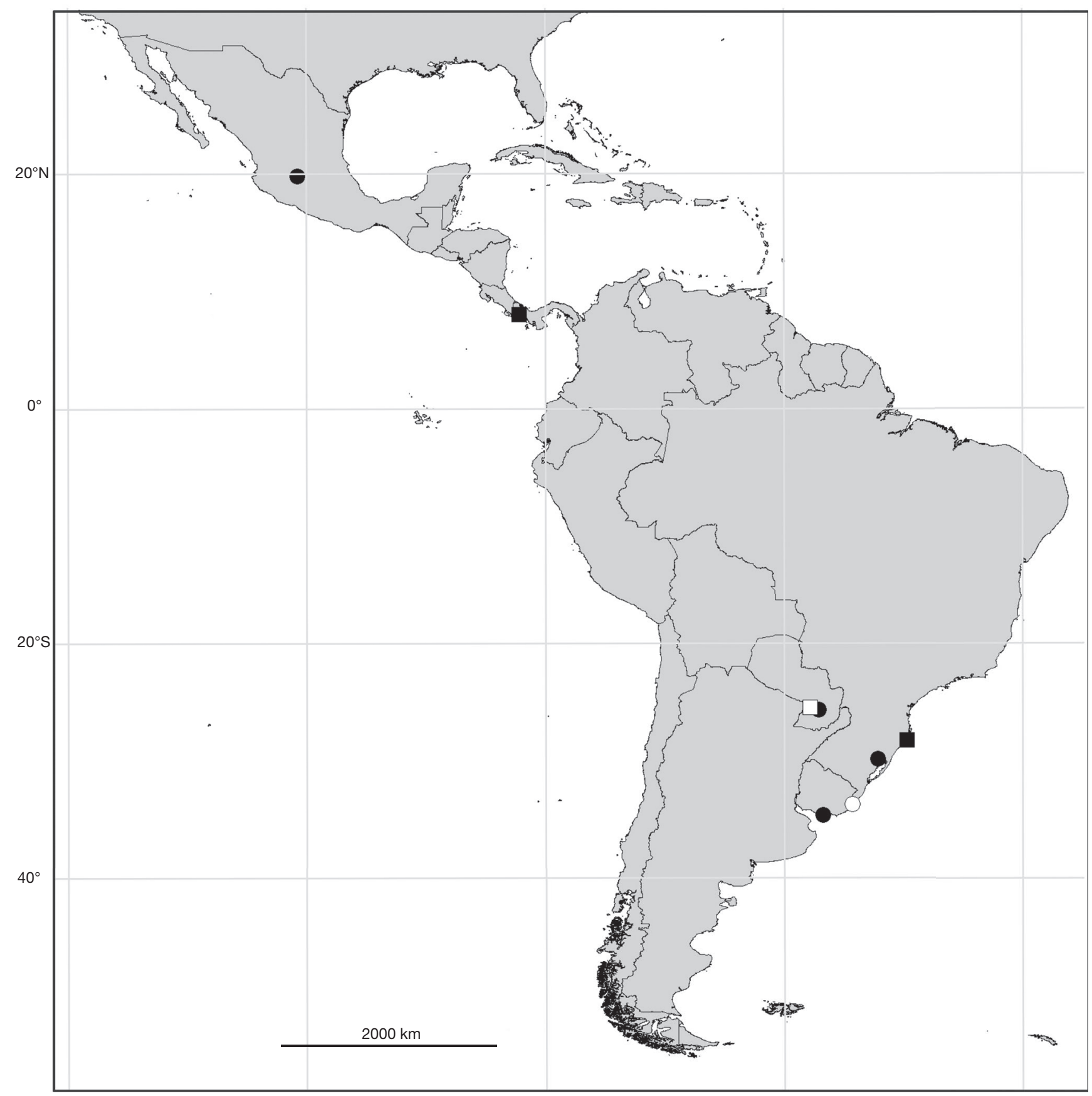

FlG. 3. - Distribution map of Tortella fruchartii (Müll. Hal.) R. H. Zander and T. lilliputana (Müll. Hal. ex G. Roth) R. H. Zander. Black circles, previously known records of $T$. fruchartii in Brazil, Mexico, Paraguay and Uruguay; empty circle, rediscovery of $T$. fruchartii in Uruguay; black squares, previously known records of $T$. lilliputana in Brazil and Panama; empty square, new record of T. lilliputana in Paraguay.

newly recorded South American samples of both species showed that in T. lilliputana an operculum exists that can be detached by a weak annulus. In the case of $T$. fruchartii, it is confirmed that the dehiscence of the capsule is due to irregular rupture.

Both Tortella species are mainly distinguished from each other by sporophytical traits that include: 1 ) the length of the seta ( $<1 \mathrm{~mm}$ in T. fruchartii vs $4-5 \mathrm{~mm}$ in T. lilliputana); 2$)$ the dehiscence mechanism of the capsule, cleistocarpous in T. fruchartii vs stegocarpous in T. lilliputana; 3 ) the presence of phaneropore stomata in the capsule of T. lilliputana, which are absent in T. fruchartii. Adittionally, some spore details obtained by LM and SEM also differ between both taxa: 4) spore diameter, $16-18 \mu \mathrm{m}$ in T. fruchartii vs $19-24 \mu \mathrm{m}$ in T. lilliputana; and 5) spore ornamentation, being rugulate in T. fruchartii and papillose in T. lilliputana (Table 1). 

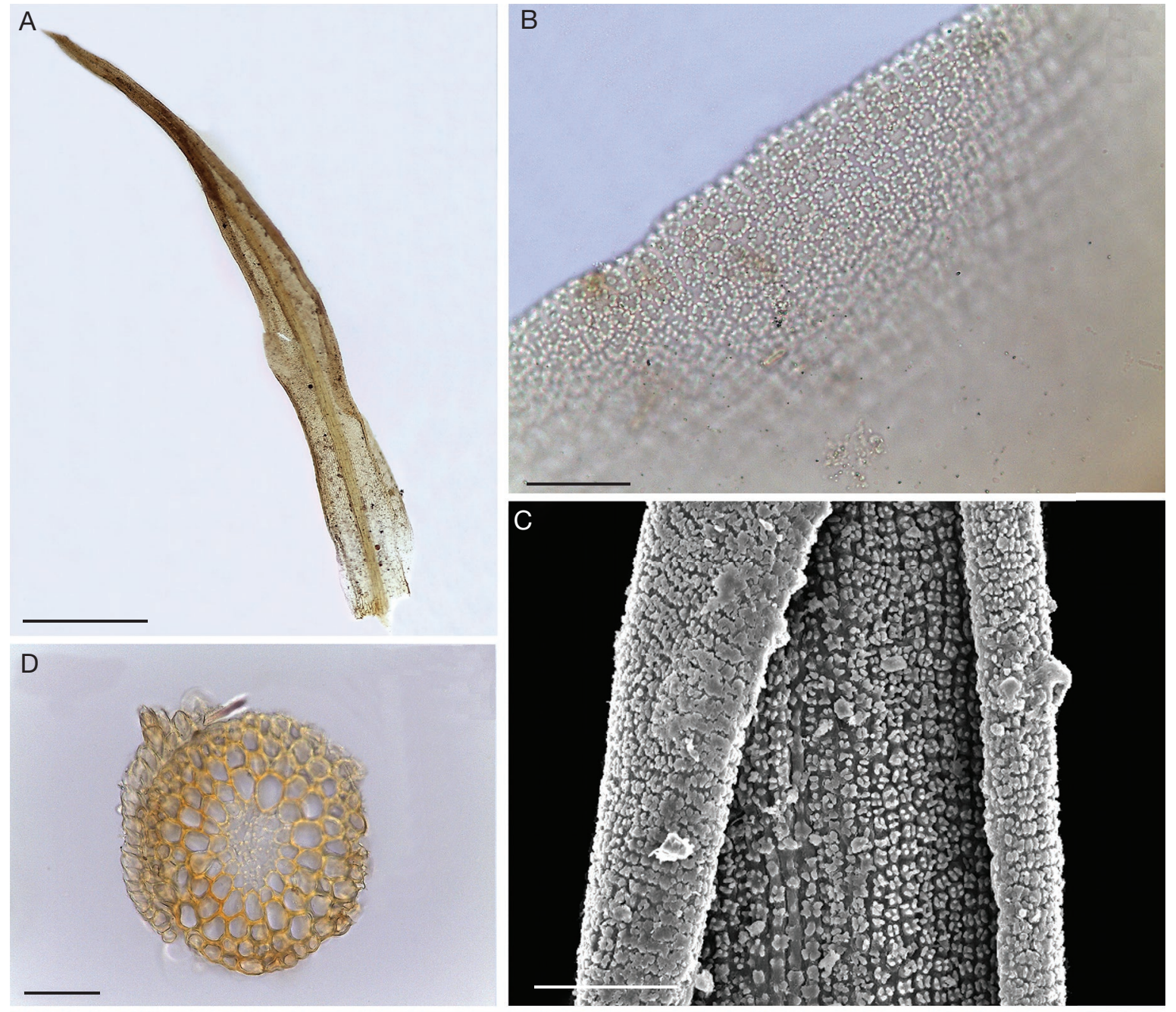

E

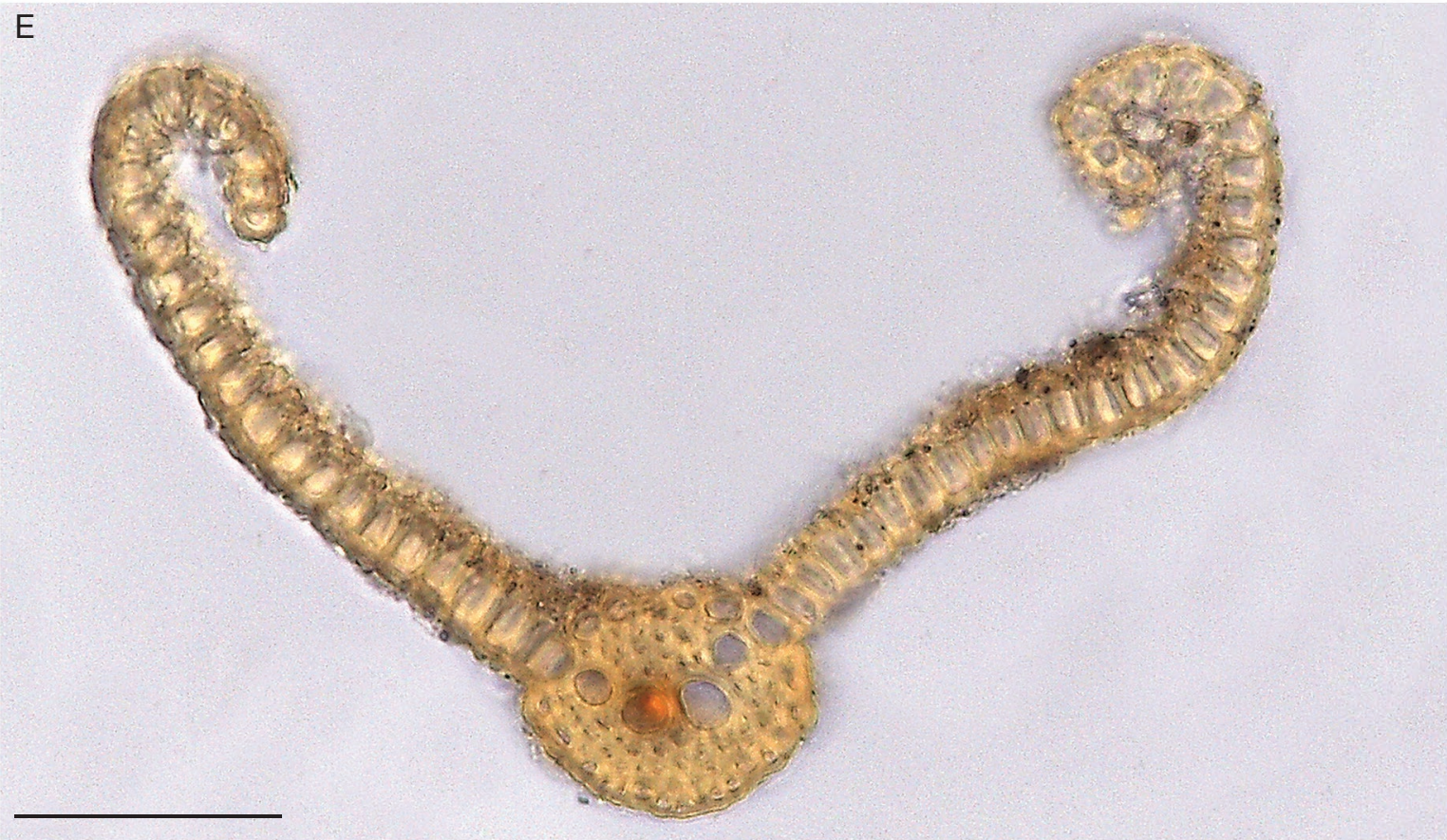

FIG. 4. - Tortella lilliputana (Müll. Hal. ex G. Roth) R. H. Zander gametophyte micrographs: A, Vegetative leaf; B, C, Laminal cells at the middle of the leaf; D, Stem cross section; E, Leaf cross section at the middle part (A, B, D, E made with LM and C with SEM). Scale bars: A, $0.5 \mathrm{~mm}$; B-E, $50 \mu \mathrm{m}$ (all from Suárez 1488, CTES). 

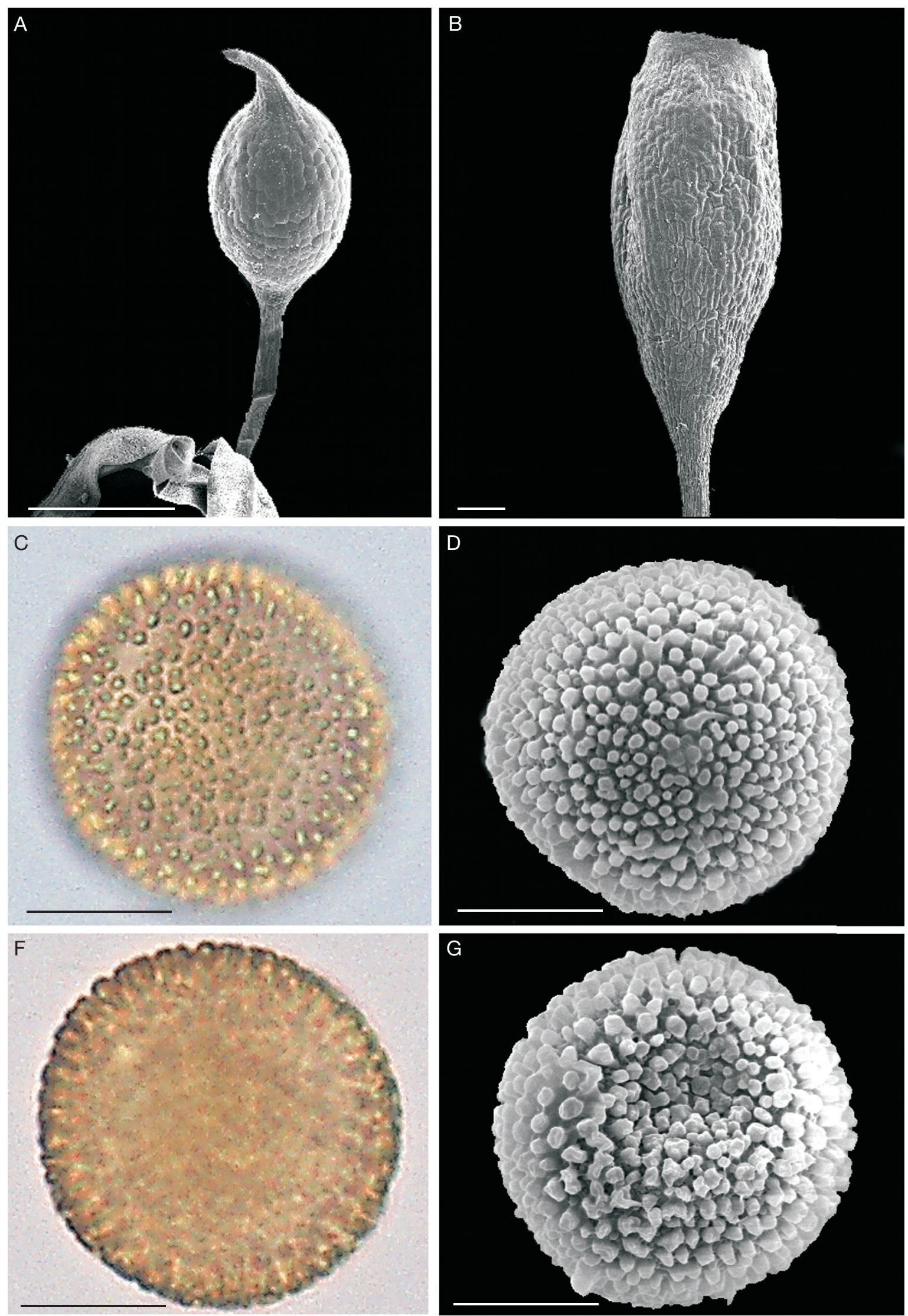

FIG. 5. - Tortella lilliputana (Müll. Hal. ex G. Roth) R. H. Zander sporophyte and spores micrographs: A, Sporophyte showing complete capsule; B, Deoperculate capsule; C, D, Spores in distal view; $\mathbf{E}$, Spore in optical view; $\boldsymbol{F}$, Spore in proximal view (A, B, D, G made with SEM and C, E with LM). Scale bars: A, B, $0.5 \mathrm{~mm}$; C-G, $10 \mu \mathrm{m}$ (all from Suárez 1488, CTES). 
TABLE 1. - Comparative diagnostic characters for Tortella fruchartii (Müll. Hal.) R. H. Zander and T. lilliputana (Müll. Hal. ex G. Roth) R. H. Zander.

\begin{tabular}{lll}
\hline & Tortella fruchartii & Tortella lilliputana \\
\hline Lenth of seta & $<1 \mathrm{~mm}$ & $4-5 \mathrm{~mm}$ \\
Capsule dehiscence & Cleistocarpous & Stegocarpous \\
Capsule stomata & Absent & Present (phaneropore) \\
Spore diameter & $16-18 \mu \mathrm{m}$ & $19-24 \mu \mathrm{m}$ \\
Spore ornamentation & Rugulate & Papillose \\
Leaves on dry & Erect-flexuose, & Erect-incurved, \\
condition & convolute & somewhat contorted \\
Margin of leaves & Plane & Incurved \\
\hline
\end{tabular}

Despite some authors consider T. fuchartii and T. lilliputana as possibly conspecific taxa (Zander 1993; Allen 2002), during this work we observed some gametophytic characters that contribute to separate them: 6) leaves on dry condition erect-flexuose, convolute in $T$. fruchartii vs erect incurved, somewhat contorted in T. lilliputana; 7) margins of leaves, plane in T. fruchartii vs incurved in T. lilliputana (Table 1).

Tortella fruchartii was included in a molecular study using nrITS sequences by Werner et al. (2005). It was resolved in a clade including also Tortella inflexa (Bruch) Broth., Trichostomum sweetii (E.B. Bartram) L.R. Stark, Trichostomum caespitosum (Bruch ex Brid.) Jur., and Weissia triumphans (De Not.) M.O. Hill, occurred at a distance of four nodes from a clade with a number of other species of Tortella. Between these two clades were found several pecies of Oxystegus (Limpr.) Hilp., Pseudosymblepharis Broth. and Chionoloma Dixon, what lead to Werner et al. (2005) to questioned the belonging of $T$. fruchartii to the genus Tortella. The cladogram of these authors may be interpreted in an evolutionary context (Zander 2017) as a basal clade of a few surviving species of an old, now much reduced Tortella lineage separated from a more modern branch of Tortella by a third clade of welldeveloped genera descendant from an ancient Tortella line. Critical is the hypothesis that T. fruchartii (and T. lilliputana) are specialized, reduced (small size, or sometimes with weak, non functional annulus) remnants of a now mostly extinct lineage of an ancient branch of what is clearly Tortella. It has been empirically demonstrated (Zander 2016, 2017) that there may be anywhere from one to four descendant species from any one progenitor, it would take a distance of at least five contiguous nodes for a morphological or molecular phylogenetic tree to be reliable as to evolutionary distance between taxa.

\section{Acknowledgements}

Thanks are owed to the curators of BM, NY, H and S for loan of specimens. This research was supported by the Argentinian National Council for Scientific and Technical Research (CONICET), Scientific and Technological Research Project (PICT) code: 0810, Research Project of the National University of Tucumán (PIUNT) code: G631, and the US American Missouri Botanical Garden. Special thanks are owed to referees to revise and to markedly improve the manuscript.

\section{REFERENCES}

Allen B. H. 2002. - Moss flora of Central America, Part 2. Encalyptaceae-Orthotrichaceae. Monographs in Systematic Botany from the Missouri Botanical Garden 90: 1-699. https://doi. org/10.21829/abm63.2003.1129

ANDERSON L. 1954. - Hoyer's solution as a rapid permanent mounting medium for bryophytes. The Bryologist 57: 242-244. https://doi.org/10.2307/3240091

Bartram E. B. 1949. - Mosses of Guatemala. Fieldiana. Botany 25: 1-442. https://doi.org/10.5962/bhl.title.2301

Boggan J., Funk V., Kellof C., Hoff M., Cremers G. \& FeuilLET C. 1997. - Checklist of the plants of the Guianas (Guyana, Surinam, French Guiana), 2nd Edition. Washington, D.C., Biological Diversity of the Guianas Program, Department of Botany. National Museum of Natural History, Smithsonian Institution, 245 p.

Brotherus V. F. 1900. — Die Laubmoose der ersten Regnellschen Expedition. Bihang till KongligaSvenskaVetenskaps-Akademiens Handlingar 3 (7): 1-65.

BUCK W. R. 1985. - Preliminary list of the mosses of Paraguay. Candollea 40 (1): 201-209.

Cañiza B. D., Peralta D. \& SuÁrez G. M. 2017. — New records and range extension of Bryophytes for Paraguay. Cryptogamie, Bryologie 38 (4): 393-410. https://doi.org/10.7872/cryb/v38. iss4.2017.393

ChurChill S. P., Griffin III D. \& MuÑoz J. 2000. - A Checklist of the Mosses of the Tropical Andean Countries. Ruizia 17: 1-203.

Churchill S. P., Sanjines N. \& Aldana C. 2009. - Catálogo de las Briófitas de Bolivia: Diversidad, distribución y ecología. Missouri Botanical Garden Press, St. Louis, 340 p.

Crum H. \& Arzeni C. B. 1953. - Additional bryophytes from Panama. Revue Bryologique et Lichénologique 22: 148-160

Delgadillo M. C., Bello B. \& Cárdenas S. A. 1995. — Latmoss. A Catalogue of Neotropical Mosses. Monographs in Systematic Botany from the Missouri Botanical Garden 56: 1-191. https:// doi.org/10.2307/2807675

Delgadillo M. C. \& Cárdenas S. A. 1996. - A preliminary checklist of the mosses of Guanajuato, Mexico, in RZEDOwSKI Rotter J. \& CALderón de RZedowski G. (eds), Flora del Bajio y de Regiones Adyacentes, Fascículo complementario 11: 1-14. Available at http://inecolbajio.inecol.mx/floradelbajio/ documentos/fasciculos/complementarios/ComplementarioXI. pdf. Accesed on 20 February 2018.

ECKEL P. M. 1998. - Re-evaluation of Tortella (Musci, Pottiaceae) in conterminous U.S.A. and Canada with a treatment of the European species Tortella nitida. Bulletin of the Buffalo Society of Natural Sciences 36: 117-191.

Ellis L. T., Asthana A. K., Sahu V., Srivastava A., BednareKOchyra H., Ochyra R., Chlachula J., ColotTi M. T., Schiavone M. M., Hradilek Z., Jimenez M. S., Klama H., Lebouvier M., Natcheva R., Pócs T., Porley R. D., Sérgio C., Sim-Sim M., Smith V. R., Söderström L., Stefnut S., SUÁREZ G. M. \& VÁNĂ J. 2011. — New national and regional bryophyte records, 28. Journal of Bryology 33 (3): 237-247. https://doi.org/10.1179/1743282011Y.0000000022

Ellis L. T., Alegro A., Bednarek-Ochyra H., Ochyra R., Bergamini A., Cogoni A., Erzberger P., Górski P., Gremmen N., Hespanhol H., Vieira C., Kurbatova L. E., Lebouvier M., Martinčič A., Asthana A. K., Gupta R., Nath V., Natcheva R., Ganeva A., Özdemir T., Batan N., Plášek V., Porley R. D., Randić M., SaWicki J., Schroder W., Sérgio C., Smith V. R., Sollman P., Stefănut S., Stevenson C. R., SuÁrez G. M., Surina B., Uyar G. \& Modrič Surina Z. 2012a. - New national and regional bryophyte records, 31. Journal of Bryology 34 (2): 123-134. https://doi.org/10.1179/1 743282012Y.0000000009

Ellis L. T., Bednarek-Ochyra H., Ochyra R., CyKOWSKa B., Dulin M. V., Ezer T., Kara R., Flores J. R., Suárez G. M., 
Garcia C., Martins A., Sérgio C., Garilleti R., Kirmac M., Agcagil E., Kurbatova L. E., Lebouvier M., Papp B., SzurDOKi E., Philippov D. A., PlásěK V., PÓCs T., SAbOVljeVić M., SaWicki J., Sim-Sim M., SzÜcs P., Bidló A., Vánă J., VigaLONDO B., LARA F., Draper I., VirChENKO V. M.\& WOLSKI G. J. 2012b. - New national and regional bryophyte records 33 Journal of Bryology 34 (4):281-291. https://doi.org/10.1179/17 43282012Y.0000000030

Flores J. R. \& SuÁREZ G. M. 2014. - Redescription of the genus Cryphidium (Cryphaeaceae, Bryophyta), with notes on its taxonomy. Boletín de la Sociedad Argentina de Botánica 49 (2): 195-199.

Flores J. R. \& SuÁREZ G. M. 2017. - Fruiting material of Chenia lorentzii (Bryophyta, Pottiaceae) found in Argentina and an evaluation of the sporophyte taxonomic value in the genus Chenia. Boletín de la Sociedad Argentina de Botánica 52 (2): $315-324$.

Gradstein R. S., Churchill S. P. \& Salazar-Allen N. 2001. Guide to the Bryophytes of Tropical America. Memoirs of the New York Botanical Garden 86: 1-77.

HE S. 1998. - A checklist of the mosses of Chile. Journal of the Hattori Botanical Laboratory 85: 103-189.

JimeneZ S. \& SuÁrez G. M. 2017. - The genus Gertrudiella Broth. (Pottiaceae, Bryophyta) in Paraguay. Check List 13 (1): 20-39. https://doi.org/10.15560/13.1.2039

Limpricht K. G. 1888. — Die Laubmoose Deutschlands, Österreichs und der Schweiz, Band 1. Leipzig, Eduard Kummer, 599 p.

MatTeri C. M. 2003. - Los musgos (Bryophyta) de Argentina. Tropical Bryology 24: 33-100. https://doi.org/10.11646/bde.24.1.8

MatTeri C. M. 2004. - The Mosses (Bryophyte) of Uruguay, their synonymy and distribution. Cryptogamie, Bryologie 25 (2): 147-167.

MCCLYMONT J. W. 1955. - Spore structure in the Musci with special reference to the genus Bruchia. The Bryologist 58: 287-306. https://doi.org/10.2307/3240311

MÜller C. 1849. - Synopsis Muscorum Frondosorum omnium hucusque Cognitorum 1: 1-812. https://doi.org/10.5962/bhl. title.31

MÜLlER C. 1888. - Musci cleistocarici novi. Flora 71: 1-14

MÜLler F. 2009. - An updated checklist of the mosses of Chile. Archive for Bryology 58: 1-124.

O'sheA B. J. \& Price M. J. 2008. - An updated checklist of the mosses of Paraguay. Tropical Bryology 29: 6-37. https://doi. org/10.11646/bde.29.1.3

O'SHEA B. J. 2010. - Mosses of Venezuela. Archive for Bryology 75: $1-23$.
Punt W., Hoen P. P., Blackmore S., Nilsson S. \& Le Thomas A. 2007. - Glossary of pollen and spore terminology, Review of Palaeobotany and Palynology 143: 1-81. https://doi.org/10.1016/j. revpalbo.2006.06.008

Roтн G. [1910-] 1911. — Die Aussereuropäischen Laubmoose. Dresden, C. Heinrich, $331 \mathrm{p}$.

SuÁrez G. M. \& SChiavone M. M. 2013. - Contributions to the moss flora of Uruguay: The genus Pohlia (Bryophyta, Bryales), a new record. Darwiniana, nueva serie 1 (1): 61-66.

SuÁrez G. M., Schiavone M. M. \& ColotTi M. T. 2014. - The genus Holomitrium (Dicranaceae, Bryophyta) in Argentina and Uruguay. Boletín de la Sociedad Argentina de Botánica 49 (2): 463-471.

SuÁrez G. M., Jimenez M. S. \& Flores J. R. 2017. — The genus Bartramia Hedw. (Bartramiaceae, Bryophyta) in Uruguay. Gayana Botanica 74 (1): 221-225. https://doi.org/10.4067/S071766432017005000111

Werner O., Ros R. M., Cano M. J. \& Guerra J. 2002. — Tortula and some related genera (Pottiaceae, Musci): phylogenetic relationships based on chloroplast rps 4 sequences. Plant Systematics and Evolution 235 (1-4): 197-207.

Werner O., Ros R. M. \& Grundmann M. 2005. - Molecular phylogeny of Trichostomoideae (Pottiaceae, Bryophyta) based on nrITS sequence data. Taxon 54: 261-368. https://doi. org/10.2307/25065364

Werner O., KÖCKInger H., Magdy M. \& Ros R. M. 2014. On the systematic position of Tortella arctica and Trichostomum arcticum (Bryophyta, Pottiaceae). Nova Hedwigia 98 (3-4): 273293. https://doi.org/10.1127/0029-5035/2014/0175

YANO O. 1981. - A checklist of Brazilian mosses. Journal of the Hattori Botanical Laboratory 50: 279-456.

ZANDER R. H. 1993. - Genera of the Pottiaceae: Mosses of Harsh Environments. Bulletin of the Buffalo Society of Natural Sciences 32: $1-378$.

ZANDER R. H. 2016. - Macrosystematics of Didymodon sensu lato (Pottiaceae, Bryophyta) using an analytic key and information theory. Ukrainian Botanical Journal 73: 319-322. https://doi. org/10.15407/ukrbotj73.04.319

ZANDER R. H. 2017. - Macroevolutionary Systematics of Streptotrichaceae of the Bryophyta and Application to Ecosystem Thermodynamic Stability. Zetetic Publications, St. Louis 232 p.

Zuloaga F. O., Morrone O. \& Belgrano M. J. (eds) 2008. Catálogo de las Plantas Vasculares del Cono Sur (Argentina, Sur de Brasil, Chile, Paraguay y Uruguay). Volumen 1. Pteridophyta, Gymnospermae y Monocotyledoneae. Monographs in Systematic Botany from the Missouri Botanical Garden 107: 1-983. 